\title{
STRATEGI BERTAHAN HIDUP MASYARAKAT KAMPUNGADAT KUTA DALAM MENGHADAPI PANDEMI COVID-19 DI KABUPATEN CIAMIS
}

\author{
Nindy Pradina \\ Politeknik Kesejahteraan Sosial Bandung, nindypradina45@gmail.com \\ Theresia Martina Marwanti \\ Politeknik Kesejahteraan Sosial Bandung, martina.wanti@gmail.com \\ Yana Sundayani \\ Politeknik Kesejahteraan Sosial Bandung, yana_sundayani@yahoo.com
}

\begin{abstract}
The impacts of Covid-19 cases have been experienced by all levels of society, including the indigenous people of Kampung Kuta. This study aims to describe survival strategies in the face of the Covid-19 pandemic by the indigenous people of Kampung Kuta. The method of this researchis descriptive qualitative research. The techniques used in this research are in-depthinterviews, participatory observation, and documentation reviews. The result shows that the active strategy was used to maximize the existing potential in the Kuta Traditional Village including physical, human, financial, social, spiritual, environmental, and technological assets in daily activities. Second, the passive strategy was used to reduce family living costs and community expenses, help each other, stay innovative, and creative for other businesses, adding up the types of agricultural crops, and marketing agricultural products to the closest people. Third,the network strategy was carried out for the utilization of networks between individuals, neighbors/families, communities, organizations/groups, traditional and village officials and even outsiders/private parties by establishing good relationships. There is support through togetherness and compactness as well as mutual cooperation activities as well as assistance from the government.
\end{abstract}

Keywords:

Survival Strategy; Covid-19; Kuta Traditional Village

\begin{abstract}
Abstrak
Dampak yang dirasakan akibat banyaknya kasus Covid-19 terasa oleh seluruh lapisan masyarakat, salah satunya oleh masyarakat adat Kampung Kuta. Penelitian ini bertujuan untuk menggambarkan strategi bertahan hidup dalam menghadapi pandemi Covid-19 pada masyarakat adat Kampung Kuta. Metode dalam penelitian ini, menggunakan penelitian kualitatif deskriptif. Teknik yang digunakan dalam penelitian ini yaitu wawancara mendalam, observasi partisipatif dan studi dokumentasi. Hasil penelitian menunjukkan strategi aktif yang dilakukan yaitu
\end{abstract}


dengan memaksimalkan potensi yang terdapat di Kampung Adat Kuta diantaranya aset fisik, manusia, finansial, sosial, spiritual, lingkungan dan aset teknologi dalam aktivitas sehari-hari. Kemudian strategi pasif yang dilakukan yaitumengurangi biaya hidup keluarga dan pengeluaran masyarakat, saling membantu, tetap berinovasi dan berkreasi untuk usaha lain, menambah jenis tanaman pertaniandan memasarkan hasil pertanian ke orang-orang terdekat. Ketiga strategi jaringan yang dilakukan yaitu pemanfaatan jaringan antar individu, tetangga/keluarga, masyarakat, organisasi/kelompok, perangkat adat dan dusun bahkan pihak luar/swasta dengan menjalin hubungan yang baik. Didukung dengan kebersamaan dan kedekatan melalui kegiatan gotong royong juga adanya bantuan dari pemerintah.

Kata Kunci:

Strategi Bertahan Hidup; Covid-19; Kampung Adat Kuta 


\section{PENDAHULUAN}

Saat ini tidak dapat dipungkiri, bahwa berbagai negara sedang mengalami kekhawatiran terhadap masalah pandemi Covid-19. Pandemi Covid-19 ialah suatu penyakit yang ditularkan oleh virus SARSCOV-2 (Virus Corona), yang saat ini penularannya telah menjangkit 213 negara di dunia, termasuk Indonesia. Data dari worldmeters hingga Selasa (28/06/2021), tercatat sebanyak 181.871.929 pasien dengan kasus positif Covid-19 dengan jumlah angka kematian hingga 3.939.223 kasus (https://news.google.co.id/).

Di Indonesia sendiri bahwa kasus Covid19 telah tercatat dari tanggal 28 Juni 2021 sebanyak 2.115.304 kasus dengan jumlah pasien sembuh 1.850 .481 orang dan kasus kematian sebanyak 57.318 pasien yang tersebar di 34 provinsi (BNPB, laporan kasus covid-19 di Indonesia). Provinsi Jawa Barat sendiri telah terkonfirmasi sebanyak 368.303 dengan jumlah kasus sembuh 319.790 serta yang meninggal dunia sebanyak 5.077 kasus (https://pikobar.jabarprov.go.id/). Disumbang dari Kabupaten Ciamis yaitu sebanyak 6279 kasus dengan pasien kasus aktif 640 dan yang meninggal 226 pasien (https://pikcovid19.ciamiskab.go.id/ )

Dilihat dari berbagai data dan banyaknya kasus diatas, bahwa pandemi Covid-19 merupakan isu permasalahan yang krusial yang sangat penting untuk diangkat, karena sangat meresahkan berbagai kalangan masyarakat. Pandemi COVID-19 ialah titik darurat sosial bahkan ekonomi secara global, yang merupakan krisis terbesar dalam beberapa generasi terakhir ini.

Pertama pada bidang pendidikan diantaranya keterbatasan guru dan siswa dalam menggunakan teknologi informasi saat belajar daring, baik dikarenakan kurangnya sarana dan prasarana, akses internet yang terbatas dan berdampak saat proses penilaian bahkan pada lulusan sekolah (Rizqon Halal Syah Aji, 2020).

Kedua pada bidang ekonomi, terjadinya penurunanan pertumbuhan ekonomi yang ekstrim, dan kerugian ekonomi karena daya jual yang menurun (Silpa Hanoatubun, 2020). Dampak lain terasa pada bidang kesehatan banyaknya tenaga kesehatan yang terinfeksi Covid-19. Kemudian pada bidang sosial, yaitu dibatasinya interaksi antar masyarakat, meningkatnya pengangguran $(5,23 \%)$ akibat pemutusan hubungan kerja, peningkatan angka kemiskinan dari bulan sebelumnya sebesar 5,71\% (Didiet Widiowati, 2020 dalam Webinar Tantangan Pembangunan Berkelanjutan untuk Indonesia 2021).

Dampak-dampak yang terjadi pun tidak luput dari salah satu bagian masyarakat yaitu masyarakat hukum adat. Masyarakat hukum adat adalah warga negara indonesia yang memiliki karakteristik khas, hidup berkelompok secara harmonis sesuai hukum adatnya, memiliki ikatan pada asal usul leluhur dan atau kesamaan tempat tinggal, terdapat hubungan yang kuat dengan tanah dan lingkungan hidup, serta adanya sistem nilai yang menentukan pranata ekonomi, politik, sosial, budaya, hukum dan memanfaatkan satu wilayah tertentu secara turun temurun (Permendagri No. 52 Tahun 2014). Sekarang penyebaran populasi masyarakat hukum adat terdapat di 28 provinsi di Indonesia, dengan jumlah persentase yang telah teregistrasi mencapai 54,14\%, terverifikasi sejumlah $3,21 \%$ dan tersertifikasi mencapai 2,54\%. Salah satunya Kampung Adat Kuta yang telah teregistrasi dan telah diakui dan dilindungi oleh 
pemerintah Kabupaten Ciamis, yang dituangkan pada peraturan daerah No. 15 Tahun 2016.

Kampung Adat Kuta berbeda dengan komunitas adat yang dijelaskan lebih lanjut oleh Surpha dalam Pitana (2005:18) yaitu perbedaan komunitas adat dengan kampung adat, yang mendeskripsikan bahwa kampung adat berlandaskan kepada kelompok tradisional yang terikat dengan adat istiadat dengan ciriciri memiliki bahasa sendiri, ada garis generasi yang sama dari penduduk asli wilayah Kampung Adat Kuta, tinggal di tanah leluhur, dan berpisah dengan kelompok masyarakat lain serta memiliki budaya yang khusus dalam kehidupan sehari-hari (Keraf (2010:362).

Kampung Adat Kuta merupakan salah satu dusun adat yang terletak di Desa Karangpaningal, Kecamatan Tambaksari, Kabupaten Ciamis. Mata pencaharian utama penduduk disana ialah sebagai petani serta mempunyai sistem keyakinan dan adat istiadat yang dipegang erat, contohnya terdapat upacara dan ritual adat masal. Kearifan lokal Kampung Adat Kuta juga diperlihatkan dengan adanya peraturan untuk berperilaku sehari-hari pada masyarakatnya, aturan adat untuk mendirikan rumah, dan aturan masuk ke tempat keramat. Berbagai karakteristik tersebut, menjadikan masyarakat adat Kampung Kuta tergolong tipe komunitas masyarakat adat kasepuhan Aliansi Masyarakat Adat Nusantara (AMAN) (2013: 28).

Hasil dari fakta di lapangan masyarakat Kampung Adat Kuta pun merasakan keresahan dan ketidaknyamanan dari dampak pandemi Covid-19 dimana masyarakat adat menyatakan bahwa mengalami kesulitan pangan dikarenakan banyak masyarakat yang tidak mempunyai penghasilan seperti biasanya, dikarenakan desa wisata adat yang dibatasi dan pemasaran hasil pertanian yang terbatas. Kampung Adat Kuta telah ditetapkan sebagai desa wisata sejak tahun 2002 oleh Kabupaten Ciamis, namun saat pandemi ini, harus ditutup sejak bulan Maret hingga Juli 2020. Namun untuk memenuhi kebutuhan desa wisata disana telah dibuka kembali di bulan Agustus yang lalu dengan prasyarat hanya bisa menampung 30 orang perharinya, padahal biasanya bisa mencapai 100 orang/harinya. Dengan kondisi ini, penghasilan masyarakat adat menurun yang juga berdampak pada perekonomian masyarakat Kampung Adat Kuta. Kedua dalam bidang pendidikan, semua anak sekolah di sana harus belajar dari rumah, tetapi kurangnya pengetahuan terhadap sistem belajar daring, bahkan membuat anak-anak lebih senang bermain gadget dibanding untuk belajar.

Dilihat dari fakta diatas, Kampung Adat Kuta memerlukan suatu strategi untuk tetap bertahan hidup dalam situasi pandemi Covid19 ini, bahkan mampu meningkatkan kemampuan untuk menerapkan semua aset komunitas dan potensi demi terwujudnya kesejahteraannya. Salah satu strategi unik yang bisa ditemukan pada masyarakat Kampung Adat Kuta saat menerapkan strategi bertahan hidup pada masa pandemi Covid-19 ini diantaranya dari segi kearifan lokal atau budayanya yang tetap dipertahankan dan menjadi nilai utama sebagai upaya mengelola tujuh aset komunitas yang ada saat keberlangsungan pandemi Covid-19 ini, salah satunya Kampung Adat Kuta tetap mempertahankan mata pencaharian sebagai petani, untuk meningkatkan ketahanan pangan saat pandemi Covid-19. Didukung oleh fakta yang lain bahwa masyarakat adat mampu bertahan hidup di masa pandemi Covid-19 
yaitu menurut pendapat Fatimah, 2021 yang menyatakann bahwa masyarakat adat menggunakan kearifan lokal dalam menghadapi wabah ini, yaitu memanfaatkan tanaman-tanaman obat yang ada disekitar lahan mereka. Tidak lupa masyarakat adat mengikuti anjuran pemerintah dengan menggunakan masker mencuci tangan serta menutup perbatasan antar desa adat dengan kota.

Sedangkan menurut Aliansi Masyarakat Adat Nusantara, 2021 juga berpendapat bahwa masyarakat adat yang aman dari pandemi Covid-19 yaitu masih menguasai wilayah dan bisa mengelola lahan dan hutan secara aman untuk kehidupan sehari-hari, yang kemudian ditegaskan saat Hari Masyarakat Adat Sedunia bahwa masyarakat adat yang bertahan di tengah krisis saat ini adalah mereka yang masih menjaga keutuhan wilayah adat dan setia menjalankan nilai maupun praktik leluhur, contohnya musyawarah adat, gotong royong, rasa senasib sepenanggungan dan memanfaatkan kekayaan titipan leluhur secara bijaksana.

Sedangkan kearifan lokal masyarakat Sasak yaitu; besiru, awik-awik \& startdem, sereat, dan sembek bisa menjadi solusi dalam mengatasi dampak disrupsi Covid-19. Itu fungsionalisasi kearifan lokal Sasak dalam mengatasi wabah Covid-19. Didukung dengan penelitian yang dilakukan oleh Rahmawati dan Muryanti \& Rohiman membuktikan bahwa adat peraturan masyarakat Dayak Banuaq dan Bambi 'Ari di Kapuas, Kalimantan Barat bisa melestarikan hutan (Sumardi, L. Wahyudiati, D. (2020)).

Berdasarkan fakta dan ketertarikan isu di atas maka Kampung Adat Kuta bisa mewakili untuk lokasi yang terkena dampak pandemi Covid-19 yang tetap mempertahankan aset yang dimilikinya sehingga sesuai dengan topik permasalahan yang diangkat oleh peneliti yaitu bagaimana Strategi Bertahan Hidup Masyarakat Kampung Adat Kuta Dalam Menghadapi Pandemi Covid-19 Di Kabupaten Ciamis baik dari strategi secara aktif, pasif, dan strategi jaringan.

Strategi aktif ialah strategi bertahan hidup yang dilaksanakan melalui pemanfaatan semua potensi yang ada, dapat dilihat melalui potensi tingkat komunitas, yang digambarkan dengan pendekatan berbasis aset. Christoper Derau (2013) menjelaskan tentang dimensi aset komunitas yang terdiri dari 7 (tujuh) aset yaitu aset manusia yang mewakili sumber daya manusia yang berkualitas baik dari unsur pengetahuan, perspektif, mentalitas, keahlian, pendidikan, kemampuan kerja, dan kesehatan yang berguna untuk meningkatkan kualitas hidup. Aset fisik berupa bangunan dan infrastruktur dasar. Aset finansial Aset dari sumber keuangan yang ada di masyarakat. Aset teknologi yang mewakili sistem dan melengkapi aset fisik. Kemudian aset lingkungan berupa sumber daya alam dan sumber daya hayati yang melingkupi suatu masyarakat serta aset sosial yang merupakan sumber daya sosial (jaringan sosial, anggota kelompok, hubungan dan kepercayaan, akses yang luas terhadap institusi sosial). Ketujuh yaitu aset spiritual berupa empathy dan perhatian, kasih sayang, dan unsur utama dari kebijakan praktis.

Aspek kedua yaitu strategi pasif ialah strategi bertahan hidup yang dilaksanakan dengan mengurangi biaya hidup agar tetap bisa mempertahankan hidupnya (Kusnadi, 2002). Ketiga yaitu aspek strategi jaringan yaitu upaya yang dilaksanakan melalui pemanfaatan jaringan sosial dengan menjalankan hubungan 
formal yang baik melalui lingkungan kelembagaan serta lingkungan sosial yang ada (Suharto, 2009). Sedangkan menurut Jensen (2003) mengemukakan bahwa istilah jaringan terdapat tiga istilah yaitu: (1) Total Network System, yang terdiri dari pola komunikasi di antara semua individu dalam sistem seperti sebuah organisasi. (2) Klik, didefinisikan sebagai sebuah elemen sistem yang saling berinteraksi satu sama lain. (3) Personal Network /Jaringan pribadi, didefinisikan sebagai orang-orang yang saling berhubungan yang dihubungkan oleh komunikasi berpola yang mengalir ke setiap individu tertentu. Prell (2012) juga menguraikan sejumlah indikator yang dapat digunakan dalam menganalisis jaringan komunikasi pada tingkat individu, antara lain: Derajat sentralitas (degree centrality) yang dapat diidentifikasi seperti pemimpin, pusat dari lingkaran gosip, orang pertama yang mendapatkan informasi, tingkat kebersamaan (betweeness) dan tingkat kedekatan (closeness).

Masalah pokok yang menjadi aspek penelitian diatas tentunya perlu suatu profesi yang bisa membantu untuk menghadapi permasalahan dalam suatu komunitas atau secara makro. Profesi tersebut adalah pekerja sosial. Definisi pekerjaan sosial ialah suatu profesi yang membantu seseorang untuk meningkatkan keberfungsian sosial baik secara individu ataupun berkelompok melalui aktivitas-aktivitas yang dipusatkan pada interaksi sosial dengan lingkungannya (Adi Fahrudin (2012:59). Penanganan masalah komunitas adat, dapat menggunakan metode makro dengan beberapa model pendekatan menurut Rothman dan Tropman, 1987 menyatakan yaitu model Locality Development yaitu melalui suatu partisipasi ataupun kontribusi aktif dari masyarakat lokal, model social planning yang memfokuskan pada proses teknik untuk memecahkan suatu masalah dan model social action yaitu suatu masyarakat akan ada bagian/kelompok yang belum mampu dan perlu untuk dibantu, diorganisasikan agar menekan struktur kewenangan yang menindasnya.

Ada beberapa strategi serta taktik yang bisa digunakan saat pelaksanaan metode makro yang dijelaskan oleh Brager et al (1987:58). Taktik dalam konsep pekerjaan sosial telah dikelompokkan menjadi tiga kategori yaitu collaboration (kolaborasi) dengan taktik implementasi; capacity building yang dapat dilakukan melalui partisipatif dan pemberdayaan. Kedua campaign (kampanye) dengan taktik edukasi, persuasif melalui cooptation dan lobbying, dan meminta bantuan massa media. Selanjutnya yaitu contest (kontes) dengan taktik bargaining \& negosiasi, aksi masyarakat dan aksi penuntutan perkara.

Profesi pekerja sosial dalam topik penelitian ini, mempunyai kontribusi penting untuk mengetahui bagaimana strategi bertahan hidup yang dilaksanakan oleh masyarakat Kampung Adat Kuta sebagai upaya mengatasi permasalahan yang dikarenakan pandemi Covid-19 dengan mengindahkan prinsip utama yaitu prinsip HAM, tanggung jawab kolektif, keadilan sosial, serta pengakuan keberagaman. Pekerja sosial dengan komunitas adat memiliki peran-peran yang harus dipenuhi yaitu fasilitator (enabler) yaitu menemukenali permasalahan, kebutuhan, potensi/ kemamapuan, serta sumber-sumber yang ada untuk didayagunakan dalam pemecahan masalah ataupun pemenuhan kebutuhan sendiri secara lebih efesien dan membantu masyarakat supaya bisa sadar akan kondisi dan situasi, 
membangkitkan motivasi guna memperbaiki serta meningkatkan sistem jaringan untuk kerjasama juga menolong dalam pembuatan perencanaan.

Peran kedua yaitu advocator sebagai wakil masyarakat yang perlu akan bantuan menuntut serta melaksanakannya demi kepentingan masyarakat. Selanjutnya peran mediator saat terjadinya konflik dari berbagai pihak. Hal yang dapat dilakukan yaitu negoisasi, kontrak sikap, mendamaikan pihak ketiga, serta berbagaimacam resolusi konflik. Peran terakhir yaitu sebagai broker dengan melaksanakan penjaringan layanan sosial, sanggup mengenali dan melokalisir sumbersumber kemasyarakatan yang sesuai, mampu menghubungkan klien dengan sumber secara konsisten serta mampu mengevaluasi efektivitas sumber dalam kaitannya dengan kebutuhan- kebutuhan masyarakat komunitas adat.

Seluruh fakta dan informasi yang telah dijelaskan, maka peneliti sangat tertarik untuk memahami bagaimana Strategi Bertahan Hidup Masyarakat Kampung Adat Kuta Dalam Menghadapi Pandemi Covid-19 Di Kabupaten Ciamis dengan berbagai pertimbangan yang telah dikemukakan.

\section{METODE}

Penelitian ini menggunakan metode kualitatif, karena sesuai dengan tujuan untuk mengkaji Strategi Bertahan Hidup Masyarakat Adat Kampung Kuta dalam Menghadapi Pandemi Covid-19 di Kabupaten Ciamis.

Sumber data yang digunakan adalah sumber data primer, yaitu data yang diperoleh secara langsung dari informan penelitian melalui teknik penelitian wawancara mendalam (indepth interview), observasi partisipasif terutama terhadap aktivitas masyarakat Kampung Adat Kuta, dan studi dokumentasi. Sumber data sekunder, yaitu data yang diperoleh dari hasil studi dokumentasi, data tersebut yang berhubungan dengan masalah strategi bertahan hidup dalam menghadapi pandemi Covid-19. Informan dalam penelitian ini yaitu Ketua adat, Lurah, RW, RT, Sesepuh, Ketua Karang Taruna, dan masyarakat yang lebih merasakan dampak pandemi Covid-19 dibandingkan yang lain.

Penentuan informan tersebut di tentukan dari teknik purposive dengan mempertimbangkan tujuan yang telah ditetapkan. Adapun kriteria informan meliputi informan adalah tokoh formal atau tokoh informal pada masyarakat yang dianggap dapat merepresentasikan situasi dan kondisi di Kampung Adat Kuta, telah melakukan suatu upaya dengan menggerakkan semua kemampuan dalam mengatasi dampak di masa pandemi Covid-19 dengan cara aktif mengerahkan semua aset yang dimilikinya, meminimalisir biaya hidup sebagai strategi pasif atau mampu berjejaring untuk mengatasi permasalahan yang timbul akibat pandemi Covid-19 dan bersedia dijadikan subjek dalam penelitian yang kemudian dapat meluangkan waktu untuk memberikan informasi kepada peneliti.

Penelitian ini juga dilakukan pemeriksaa keabsahan data melalui uji kredibilitas data (Credibility), dilihat dari ketekunan pengamatan, triangulasi dengan tujuan untuk memeriksa keabsahan informasi dan data. Pada langkah ini peneliti menggunakan tiga jenis triangulasi yaitu sumber, waktu serta metode serta dari kecukupan referensi. Setelah itu dilakukan uji 
kepastian data (confirmability) dengan menggunakan teori objektivitas.

Berdasarkan konsep tersebut peneliti melaksanakan audit kepada dosen pembimbing, aparat desa dan masyarakat sekitar Kampung Adat Kuta diluar dari informan penelitian. Kemudian di uji kebergantungan data (dependability) melalui pengecekan pada semua proses penelitian dari berbagai proses bimbingan dengan dosen pembimbing, dan terakhir dilakukan uji keteralihan (transferability) melalui uraian rinci (thick description) serta melaporkan dengan teliti dan cermat hasil penelitian sehingga bisa menggambarkan konteks tempat penelitian dilaksanakan.

Selanjutnya data yang diperoleh dari lapangan di analisis melalui model Miles \& Huberman. Kegiatan analisis diawali dengan reduksi data melakukan penajaman, pengarahan, penggolongan dan pembuangan data yang tidak digunakan, serta pengorganisasian informasi yang sesuai sehingga tercipta sebuah kesimpulan yang ditarik dan diverifikasi sebelumnya. Kemudian melakukan penyajian data dengan tulisan yang bersifat naratif dalam bentuk matriks, chart ataupun grafik dan ditarik sebuah kesimpulan dari data dan informasi yang telah dikumpulkan berupa gambaran ataupun deskripsi dari rumusan ataupun fokus masalah penelitian yaitu meliputi karakteristik informan, strategi secara aktif, pasif dan jaringan yang dilakukan informan sebagai upaya strategi bertahan hidup saat pandemi Covid-19 dan harapan informan terhadap situasi tersebut.

\section{HASIL PENELITIAN \\ Gambaran Lokasi}

Kampung Adat Kuta berasal dari kata Mahkuta, yang berarti kepangkatan dan menurut tradisi lisan bahwa Kampung Kuta merupakan daerah yang sempat akan dijadikan pusat Kerajaan Galuh pada masa Prabu Permanadi Kusuma, yang tepatnya terletak di Leuweung Gede, namun dibatalkan karena kurang luas. Kemudian Leuweung Gede dan tempat-tempat penyimpanan bahan bangunan yang ditetapkan sebagai tempat keramat, untuk memelihara dan menjaganya ditetapkan seorang Juru Kunci (Kuncen). Kuncen pertama yaitu Aki Bumi dan wafat, digantikan oleh Aki Danu, kemudian Aki Surabangsa, Aki Mainah, Aki rasipan, Aki Karsan, Aki Amirta, Aki Sanusri, Aki Madtasri (1977-2000), Aki Maryono (2000-2015), Aki Karman (20022010) dan Aki Warsim Setiaman (2010sekarang).

Kondisi geografis Kampung Adat Kuta yaitu berada di wilayah Desa Karangpaninggal, Kecamatan Tambaksari, Kabupaten Ciamis, Jawa Barat yang berada di lembah yang dikelilingi oleh tebing yang curam setinggi 30$60 \mathrm{~m}$. Adapun batas wilayah di Kampung Adat Kuta itu sendiri dibatasi di sebelah utara yaitu Dusun Margamulya, sebelah timur Sungai Cijolang dan Jawa Tengah, bagian selatan Desa Bangunharja dan sebelah Barat yaitu Dusun Ciloa.

Secara topografi Kampung Adat Kuta terletak pada ketinggian $\mathbf{\pm 4 6 3}$ mpdl diatas permukaan air laut dengan luas lahan 185,195 Ha yang digunakan secara produktif untuk lahan pertanian sawah, hutan lindung dan pemukiman. Hal ini didukung dengan tata air (hidrologi) yang berasal dari sungai Cijolang 
mengaliri area sawah dan permukiman serta iklim yang baik untuk lahan pertanian.

Jumlah penduduk Kampung Adat Kuta sampai dengan akhir tahun 2020 sebanyak 253 jiwa atau $120 \mathrm{KK}$ terdiri dari Laki-laki 119 jiwa dan perempuan 134 jiwa. Berdasarkan kelompok usia jumlah penduduk paling banyak terdapat pada rentang 15-64 tahun sebesar 199 jiwa $(78,62 \%)$ yang menunjukkan bahwa masyarakat Kampung Adat Kuta banyak yang bisa bekerja untuk memenuhi kebutuhan hidupnya, namun banyak masyarakat adat yang ditemukan belum maksimal penghasilannya dikarenakan jenis pekerjaan yang relatif sama yaitu mayoritas sebagai petani sebesar 183 (72,33\%), yang tidak bisa berkompetisi disebabkan kualitas SDM yang masih rendah dilihat dari jumlah masyarakat yang rata-rata pendidikan dengan tamatan SD terbesar dibandingkan dengan tingkat pendidikan lainnya, yaitu sebesar 169 jiwa $(66,79 \%)$ dan keterbatasan keterampilan. Permasalahan tersebut mengakibatkan belum terpenuhinya kebutuhan hidup masyarakat adat karena harga barang tidak sebanding dengan penghasilan yang didapatkan.

Berdasarkan hal tersebut, maka penduduk Kampung Adat Kuta dapat digolongkan menjadi penduduk yang memiliki tingkat pendapatan menengah ke bawah dengan rata-rata jumlah pendapatan masyarakat yang memiliki mata pencaharian petani yaitu kurang lebih Rp. Rp.700.000/bulan, hal ini sesuai dengan studi dari Banerjee \& Duflo, 2008; ADB, 2010 yang menyatakan bahwa kelas menengah ke bawah memiliki pendapatan lebih dari US\$ 2 PPP s.d. US\$ 4 PPP per kapita per hari.

Mata pencaharian lainnya yaitu sebagai pedagang dan pengrajin gula aren yang merupakan olahan khas Kampung Adat Kuta yang biasanya dijual kepada pengunjung yang datang ke wisata adat Kampung Kuta. Kondisi perumahan masyarakat Kampung Adat Kuta sendiri cenderung linier. Biasanya kumpulan rumah yang dibangun berdekatan tersebut, pemiliknya memiliki hubungan kerabat dekat. Rumah-rumah masyarakat adat Kampung Kuta relatif memiliki bentuk yang sama karena dalam mendirikan rumah, hal ini terjadi karena terikat oleh aturan adat baik dalam bentuk maupun bahan bangunan yang harus digunakan. Semua rumah disini memiliki bentuk panggung dan berbahan kayu tidak boleh tembok serta atap terbuat dari rumbia atau ijuk. Tempat masak yang digunakan yaitu tungku dan fasilitas MCK berasal dari satu tempat umum dan bersumber dari mata air. Kampung Adat Kuta mengambil sumber air menggunakan jeriken untuk wudhu, masak, dan buang air kecil, sedangkan untuk mandi, mencuci dan BAB dilakukan di kolam yang dibuat untuk seluruh masyarakat adat.

Struktur kepemimpinan masyarakat Kampung Adat Kuta pada umumnya berbeda dengan dusun-dusun yang lain, karena mencakup dua bentuk organisasi dalam satu wilayah yaitu ada sistem lembaga pemerintahan formal dan sistem lembaga pemerintahan non formal yaitu sistem kepemimpinan adat yang keberlangsungan berjalan bersama guna mencapai tujuan. Hal ini dapat dilihat dari penggunaan istilah-istilah yang sama untuk struktur kepemimpinan di masyarakat yaitu RT, RW, Kepala Dusun, dan organisasi adat yaitu Ketua Adat dan Kuncen.

Sistem nilai dan budaya yang berkembang diwariskan oleh leluhur yang masih dipegang erat. Salah satu bentuk dari terlaksananya kearifan lokal masyarakat adat Kampung Kuta yaitu aturan berperilaku seharihari, aturan adat membangun rumah, 
memasuki tempat-tempat keramat serta adat istiadat kehamilan, sunatan dan gusaran, perkawinan bahkan upacara-upacara adat yang masih tetap terjaga kelestariannya seperti ritual nyuguh, babarait, nebus weteng dan nyangkreb (nyalin). Penduduk Kampung Adat Kuta Kecamatan Tambaksari didominasi oleh etnis Sunda. Pembauran antara penduduk di Kampung Adat Kuta terlihat sangat baik, hal tersebut dibuktikan dengan hubungan timbal balik dan sikap saling menghormati yang baik antara satu sama lainnya. Nilai gotong royong juga masih dijunjung tinggi, yang berfungsi untuk saling membantu dalam memenuhi kebutuhan sehari-hari yang dapat dibuktikan dengan kerja sama yang dapat digambarkan melalui kegiatan ronda malam. Selain itu, sifat kepedulian di Kampung Adat Kuta yang masih kuat membuat warga saling membantu satu sama lain. Seperti renovasi rumah warga, melaksanakan hajatan, membersihkan lingkungan desa, pembuatan jalan, dan infrastruktur desa lainnya. Mencakup juga kepedulian warga terhadap warga lain yang sedang terkena musibah seperti sakit dan meninggal dunia. Terlepas dari hal tersebut, penduduk Kampung Adat Kuta masih erat dengan tradisi ritual adat peninggalan leluhur.

Kemudian sistem pelayanan kesejahteraan sosial yang ada di Kampung Adat Kuta memang dapat dikatakan cukup baik. Hal ini dapat dilihat dari berdirinya beberapa lembaga kesejahteraan sosial karang taruna, PKK, UPZ, MUI, BPD, dan LPM. Sistem pelayanan kesejahteraan sosial di masyarakat Kampung Adat Kuta masih terfokus pada bidang kesehatan yaitu seperti kegiatan posyandu dan berkaitan dengan bantuan sosial dari pemerintah seperti PKH, BPNT, KIS,KIP, posyandu dan bantuan Covid-19.

\section{Karakteristik Informan}

Informan dalam penelitian ini berjumlah tujuh orang yang terdiri dari pemerintah adat, pemerintah dusun dan masyarakat adat Kampung Kuta yang paham akan kondisi dan situasi saat pandemi Covid-19, sehingga merasakan dampak dan melakukan berbagai strategi untuk tetap bertahan hidup. Pertama informan WR yang merupakan Ketua Adat berusia 45 tahun. Kemudian DL sebagai Ketua RT.01/RW.04 berusia 58 tahun, dilanjutkan oleh informan WJ berusia 75 tahun sebagai aki sepuh yang mengetahui seluruh sejarah di Kampung Adat Kuta, yang merupakan keturunan dari leluhur disini sehingga memiliki buku sejarah dan paling fasih dalam menceritakan sejarah disini. Keempat ada AN sebagai ketua karang taruna IRA dan ada DS sebagai kepala dusun dan $\mathrm{KN}$ sebagai perwakilan salah satu masyarakat yang pernah merantau ke Jakarta, namun setelah pandemi menjadi salah satu yang terkena dampaknya, sehingga kembali ke Kampung Kuta bersama suaminya dan sekarang bekerja sebagai pedagang dan suaminya bekerja sebagai petani. Terakhir adalah informan RW sebagai ketua RW

Strategi Aktif untuk Bertahan Hidup dalam Menghadapi Pandemi Covid-19 pada Masyarakat Kampung Adat Kuta di Kabupaten Ciamis

Berdasarkan data di lapangan, dapat diketahui bahwa aset komunitas yang dimiliki oleh Kampung Adat Kuta terdiri dari tujuh aset komunitas, pertama aset fisik yaitu berupa infrastruktur seperti mushola untuk tempat beribadah, aula adat yang dijadikan sebagai pusat kumpul dan pos ronda. Aset selanjutnya adalah aset manusia yang di repsentasikan melalui seluruh perangkat adat maupun dusun, 
yaitu kepala dusun, ketua adat, sekretaris, bendahara, ketua RW, RT, Karang Taruna, anggota kelompok tani, LPM, BPD, DKM, MUI dan yang lainnya. Ketiga, aset yang dimiliki oleh masyarakat adat Kampung Kuta adalah aset finansial yang diperoleh dari beberapa iuran seperti iuran beras "perelek", iuran per bulan yang berjumlah Rp.3000,00/bulan, dan ada iuran infaq yang berjumlah Rp.1000,00 minimal dan maksimalnya tidak terhingga, ada juga iuran insidental ketika akan mengadakan kegiatankegiatan gotong royong untuk membersihkan wilayah Kampung Kuta dan pemasukan yang berasal dari pengunjung wisata adat Kampung Kuta serta CSR dari Gudang Garam yaitu PATRA untuk pemberdayaan masyarakat dan beberapa sponshorsip dari beberapa individu.

Selanjutnya adalah aset sosial, hal ini merupakan aset yang cukup menonjol yang dimiliki oleh Kampung Adat Kuta, yaitu nilai gotong royong atau kerja sama sangat erat, melalui berbagai kegiatan-kegiatan masyarakat adat. Aset kelima yaitu aset spiritual, terdapat pengajian rutinan yang dilakukan setiap hari Jumat pagi, adanya DKM dan perayaan hari besar serta terdapat organisasi pengelolaan dana infaq, shodaqoh dan zakat. Kemudian pada aset lingkungan, yang sangat diakui, dijaga dan dilestarikan oleh masyarakat adat Kampung Kuta. Alam disini dihemat, dipelihara dan dimaksimalkan, semua lingkungan dilestarikan sesuai dengan sosial budaya yang melekat menjadi kebiasaan. Lingkungan Kampung Adat Kuta dikelilingi oleh tebing, sawah, dan kebun. Selain itu juga terdapat hutan keramat yang menjadi hutan lindung, beberapa peninggalan leluhur yaitu gunung semen, batu goong, mata air dan terdapat sungai, juga terdapat danau ranca bogo yang dulunya merupakan sawah dan terendam menjadi pemandangan yang indah dan dikembangbiakkan ikan. Semua informasi tersebut diberikan informan RW dan DS serta didukung dari hasil observasi dan studi dokumentasi oleh peneliti, yang dapat dilihat dari kotak berikut:

"Upami wisata di Kampung Adat Kuta parantos lami, aya sejarah sareng ayeuna dijagaan ku masarakat adat di dieu. Aya hutan keramat, titilar gunung, batu goong sareng ranca bogo. Aya sababaraha poténsi anu dipimilik sacara pribadi, nyaéta Ranca Bogo aya 19 urang” (RW)

"Poténsi ieu dipiboga sacara pribadi, sapertos sawah, kebon, bumi sareng sasarengan, nyaéta adat istiadat, hutan keramat sareng jalan / prasarana, anceman sapertos gunung jeung mata cai ciasihan neng” (DS)

"Kalau wisata di Kampung Adat Kuta udah dari dulu de, ada sejarahnya dan sekarang di jaga sama masyarakat adat disini. Ada hutan keramat, peninggalan-peninggalan gununggunung, batu goong dan ranca bogo. Ada beberapa potensi itu ada yang dimiliki secara pribadi de, yaitu ranca bogo ada 19 orang" (RW)

"Potensi-potensi tersebut ada yang milik secara pribadi seperti sawah, kebun, rumah dan kalau yang secara bersama yatu adat istiadat, hutan keramat dan jalan/sarana prasarana, anceman seperti gunung dan mata air ciasihan" (DS)

Faktor penunjang untuk aset lingkungan yaitu aset teknologi. Teknologi yang sudah dipakai yaitu traktor sejak 20 tahun yang lalu, motor, dan ponsel. Letak semua potensi yang ada pada masyarakat adat Kampung Kuta ada yang dimiliki secara pribadi dan juga secara 
bersama. Perbedaan keduanya adalah dalam pengelolaan semua aset potensi tersebut, jika dimiliki secara pribadi maka semua proses dalam pengelolaan dan hasil yang diterima akan digunakan secara pribadi yaitu dalam lingkup kecil baik individu ataupun keluarga, sedangkan jika dimiliki secara bersama maka proses pengelolaan dan hasilnya pun digunakan secara bersama yaitu seluruh masyarakat adat Kampung Kuta.

Semua tujuh aset komunitas yang dimiliki oleh Kampung Adat Kuta masih tetap digunakan oleh masyarakat adat, bahkan sebelum dan sekarang saat pandemi Covid-19. Aset fisik yang digunakan tetap mengindahkan protokol kesehatan yang dicanangkan oleh pemerintah. Kedua, aset manusia tetap tetap menjalankan tugas masing-masing baik perangkat adat dan perangkat dusun. Aset finansial pun tetap berjalan untuk membantu pelaksanaan kegiatan rutinan yang ada disana, membantu masyarakat adat yang mendapatkan musibah, bahkan membantu masyarakat yang sedang melakukan hajatan, pembuatan rumah, melahirkan, dan ada yang meninggal. Semua kegiatan tersebut dibantu melalui aset finansial yang mereka miliki. Pemasukan dari pengunjung yang masuk ke desa wisata adat dan juga dibantu oleh CSR Gudang Garam, "PATRA" dan sponsorship dalam pemberdayaan masyarakat bahkan saat pandemi juga membantu dalam pengadaan alat untuk protokol kesehatan seperti cek suhu, masker dan tempat pencuci tangan.

Semua kegiatan yang ada pada masyarakat adat seperti ritual tahunan, kegiatan hajatan, pembuatan rumah, melahirkan dan ada yang meninggal pun tetap berjalan dengan semestinya namun memang tetap mematuhi protokol kesehatan 3M. Namun interaksi, hubungan komunikasi antar masyarakat tetap terjalin dengan baik melalui gotong royong pada kegiatan-kegiatan diatas dan penukaran informasi pun tetap terjalin saat masyarakat adat saling berkumpul pada lingkaranlingkaran gosip di warung atau pos ronda, bahkan ketika ada yang kekurangan masyarakat adat saling membantu seperti keluarga sendiri.

Aset lingkungan pun tetap digunakan saat pandemi Covid-19, semua masyarakat adat tetap beraktivitas di sawah, kebun, dan sungai, dimulai dari pagi hari hingga sore hari, serta tetap menggunakan peralatan yang menunjang pekerjaan yaitu traktor dan motor. Sedangkan ketika ada pengunjung yang masuk ke wilayah Kampung Adat Kuta, tetap diperbolehkan namun harus menjaga protokol kesehatan dan pengetatan izin masuk, semua pengunjung bisa datang ke hutan keramat untuk ziarah, menikmati pemandangan di ranca bogo, gunung, batu goong dan tebing. Penggunaan ponsel pun tetap digunakan oleh anak-anak Kampung Adat Kuta untuk bersekolah online dari rumah.

Tidak bisa dipungkiri saat melakukan strategi bertahan hidup masyarakat adat terkendala seperti adanya kebijakan dari pemerintah harus patuh $3 \mathrm{M}$, kurangnya dana yang masuk diakibatkan dari kurangnya pengunjung yang masuk ke wilayah Kampung Adat Kuta, turunnya harga hasil bumi dari sawah atau kebun, bahkan ada beberapa yang tidak diterima oleh penjual serta kondisi alam yang kadang-kadang tidak bisa ditebak, serta terbatasinya gerak masyarakat untuk menjual hasil alam keluar wilayah bahkan tidak bisa mencari sponsorship untuk pengembangan Kampung Adat Kuta. Kemudian, salah satu informan merasakan kurangnya SDM yang 
berinovasi dan berkreasi untuk pengembangan Kampung Adat Kuta.

Walaupun ada beberapa aset komunitas yang ada di Kampung Adat Kuta tidak berjalan dengan semestinya, namun masyarakat adat tetap berupaya untuk memaksimalkan potensi yang ada guna menghadapi pandemi Covid-19. Upaya-upaya yang dilakukan masyarakat Kampung Adat Kuta yaitu menambah variasi pekerjaan, misalnya dengan berjualan. Strategi lain yang dilakukan oleh masyarakat adat Kampung Kuta yaitu menjual hasil tani melalui sosial media seperti whatsapp yang dibagikan lewat status masing-masing, nanti barangnya akan diambil oleh pembeli.

\section{Strategi Pasif untuk Bertahan Hidup dalam Menghadapi Pandemi Covid-19 pada Masyarakat Kampung Adat Kuta di Kabupaten Ciamis}

Strategi pasif ialah strategi bertahan hidup yang dilaksanakan dengan mengurangi biaya hidup masyarakat. Strategi ini dilakukan untuk menghadapi dampak dari pandemi Covid-19, yang dirasakan oleh masyarakat Kampung Adat Kuta yaitu dalam beberapa bidang, yaitu:

\section{Bidang Perekonomian}

Bidang yang paling dirasakan oleh masyarakat adat Kampung Kuta, dimana desa wisata adat Kampung Kuta pun ditutup sementara dan sekarang adanya pembatasan jumlah pengunjung. Biasanya pengunjung yang masuk kurang lebih 20-50 orang/hari, dan sekarang untuk mencapai 50/bulan saja sangat sulit. Bahkan menurut RW pernah ada pengunjung dengan jumlah 400/hari untuk melakukan studi banding. Selain pengunjung yang ingin melakukan ziarah, mahasiswa yang akan melakukan penelitian atau KKN pun tidak diperbolehkan jika jumlahnya yang melampaui batas. Sekarang mahasiswa yang diperbolehkan masuk sekitar 1-5 orang saja, namun tetap diperketat izinnya. Biasanya jumlah mahasiswa yang akan KKN dan penelitian sangat banyak, bahkan dosen pun ikut meneliti di Kampung Adat Kuta. Semua pemasukan dari pengunjung wisata pun turun, sehingga mengakibatkan pemasukan untuk masyarakat adat pun berkurang. Informasi tersebut sesuai dengan informasi dari DS dan WJ yang menyatakan di Kotak dibawah ini :

"Mun dampak pandemi Covid-19 didieu mah nu paling karasa nyaeta desa wisata neng, nu biasana seeur, nyampe meureun nu ulin teh 20 per poe nu bade ziarah, atawa mahasiswa, dosen atawa pelajar nu rek di ajar di Kampung Kuta” (DS)

"Kalau dampak pandemi Covid-19 disini yang paling kerasa desa wisata neng, yang biasanya banyak pengunjung bisa nyampe 20 orang perhari baik yang ziarah bahkan mahasiswa, dosen atau pelajar yang mau belajar di Kampung Kuta" (DS)

Selain itu berdampak pada penjualan hasil pertanian seperti padi, gula aren, pisang, yang biasanya bisa dipasarkan ke luar wilayah Kampung Adat Kuta, sampai ke Rancah, Banjarsari Cirebon, dan Kuningan. Tapi sekarang tidak bisa, karena adanya pembatasan ke luar wilayah, jadi yang membeli hasil pertanian adalah orang-orang terdekat di Kampung Adat Kuta sendiri dan ada beberapa orang terdekat di Desa Karangpaninggal, itupun pembeli yang mengambil barangnya. Selain sulit untuk pemasaran, harga jual pun turun dengan drastis, paling mencapai setengah harga dari biasanya, bahkan ada beberapa hasil pertanian seperti pisang tidak diterima oleh 
tengkulak. Hal ini mengakibatkan penghasilan masyarakat adat Kampung Kuta menurun, padahal pengeluaran tetap sama. Hal tersebut sesuai informasi yang disampaikan oleh DS yaitu pada kotak dibawah ini :

\begin{tabular}{|l|}
\hline "Dina hal kagiatan masarakat sadidinten, \\
pangaruhna henteu katingali teuing, \\
kumargi sadidinten di kebon, tapi \\
pangaruhna kusabab harga jual produk \\
tatanén masih luhur, sateuacan pandemi, \\
cau 3000/kg. Kadang-kadang éta henteu \\
dicandak ku tengkulakteh"(DS) \\
\hline "Kalau aktivitas-aktivitas sehari-hari \\
masyarakat tidak terlalu keliatan dampaknya, \\
karena emang sehari-hari di sawah, tapi \\
berdampak karena harga jual hasil tani nya \\
neng, pisang juga sebelum pandemi 3000/kg \\
kalau sekarang 1000/kg aja susah neng, \\
soalnya kadang pada gak diambil sama \\
tengkulaknya" (DS)
\end{tabular}

\section{Bidang Pendidikan}

Banyak anak-anak di Kampung Adat Kuta melaksanakan sekolah online dari rumah, dan yang offline bisa dihitung 2-5 kali dalam 1,5 tahun ini. Namun, banyak anak-anak di Kampung Adat Kuta tidak mendapat tugas dari sekolah dan tidak belajar di rumah. Sedangkan ada tugas, yang mengerjakan adalah orangtuanya. Hal ini membuat orang tua khawatir akan kondisi anak-anak sekolah. Sedangkan pada tingkat SMP dan SMA jika akan mengerjakan tugas bersama temantemannya, harus menempuh jarak yang cukup jauh, dikarenakan tempat sekolahnya berada di Kecamatan Tambaksari, Rancah dan Banjar. Kendala itupun yang membuat anak-anak Kampung Adat Kuta untuk tidak mau pergi mengerjakan tugas.

\section{Bidang Sosial Budaya}

Adanya pembatasan interaksi antar satu masyarakat dengan yang lainnya, sehingga ada beberapa kegiatan yang dibatasi seperti ritualritual yang dilaksanakan hanya dengan masyarakat adat Kampung Kuta. Kegiatan lain seperti hajatan, lahiran, dan pengajian dilaksanakan dengan pembatasan jarak, jumlah dan waktu.

\section{Bidang kesehatan}

Tidak terlalu terdampak, dikarenakan masyarakat disana mengandalkan apotik hidup untuk berobat, yaitu melestarikan dan menjaga alam. Namun, jika ada yang mengalami sakit parah maka akan dibawa ke rumah sakit Banjar atau Dadi Keluarga Kawali. Namun saat pandemi ini, masyarakat adat Kampung Kuta jika merasakan sakit akan pergi ke puskesmas desa yang terletak cukup jauh di dekat Kantor Desa Karangpaninggal. Tetapi saat ada masyarakat yang pulang dari wilayah lain harus melakukan isolasi mandiri selama 14 hari di rumahnya masing-masing dan pengunjung yang akan menginap maka diwajibkan memberikan surat sehat atau bebas dari Covid19.

\section{Bidang politik}

Tidak terlalu berdampak, namun informan RW menyatakan bahwa ada kegiatan pembuatan kebijakan tertunda. Selain itu, dana yang seharusnya turun untuk pembuatan infrastruktur ditunda dikarenakan dana yang akan diberikan disalurkan kepada pemulihan ekonomi dampak pandemi Covid-19.

Dampak-dampak pandemi Covid-19 tidak membuat masyarakat adat Kampung Kuta berhenti untuk berupaya, salah satunya adanya pemasukan dari beberapa masyarakat seperti iuran beras "perelek", iuran per bulan, iuran infaq dan iuran insidental akan digunakan 
ketika akan mengadakan kegiatan-kegiatan serta pemasukan yang berasal dari pengunjung wisata adat Kampung Kuta serta CSR dari Gudang Garam dan beberapa sponshorsip dari beberapa individu yang dikelola oleh Karang Taruna IRA (Ikatan Remaja Adat) Kampung Kuta.

Semua pemasukan tersebut digunakan untuk membantu masyarakat adat yang mengurangi kekurangan akibat dampak pandemi Covid-19 dan tetap bisa bertahan hidup untuk memenuhi semua kebutuhan sehari-hari. Upaya lain yang dilaksanakan oleh masyarakat adat Kampung Kuta untuk tetap bertahan hidup dalam masa pandemi Covid-19 yaitu dengan mengurangi biaya hidup seharihari, dimana untuk biaya makan masyarakat adat Kampung Kuta mengambil dari hasil alam seperti padi dan sayuran untuk lauk pauk. Kemudian hasil pertanian, peternakan, perikanan yang diperoleh dibagi menjadi dua yaitu untuk makan sehari-hari dan sisanya akan dijual untuk memenuhi kebutuhan lainnya seperti kuota, listrik, bahan bakar, dan pembelian kebutuhan pertanian yaitu pupuk dan penghilang hama. Selain dari itu, masyarakat adat juga memanfaatkan hasil alam, seperti pupuk kandang akan digunakan untuk memupuk tanaman pertaniannya. Hal ini sedikit mengurangi anggaran makanan dan biaya hidup sehari-hari.

Strategi lain yang dilakukan oleh masyarakat adat Kampung Kuta yaitu yaitu dengan membeli hewan ternak sebagai aset untuk disimpan, yang akan digunakan kedepannya seperti ayam, ikan, sapi, dan kambing ketika ada lebih dari sisa pengeluaran sehari-hari, menambah jenis tanaman yang ditanam di sawah atau kebun, meningkatkan pertahanan keluarga yang diserahkan kepada pengelolaan keluarga masing-masing dan saling membantu dengan tetangga dan saudara ketika ada yang membutuhkan. Selain itu, memperpanjang jam kerja dan mengajak anggota keluarga lain untuk membantu bekerja di sawah atau kebun. Bahkan ada yang menginap karena jaraknya yang jauh.

\section{Strategi Jaringan untuk Bertahan Hidup dalam Menghadapi Pandemi Covid-19 pada Masyarakat Kampung Adat Kuta di Kabupaten Ciamis}

Strategi jaringan adalah strategi bertahan hidup yang dilaksanakan oleh masyarakat adat Kampung Kuta dengan menjalankan hubungan formal yang baik melalui lingkungan kelembagaan serta lingkungan sosial yang ada. Selain itu dapat di gambarkan melalui jumlah network system yang terdiri dari pola komunikasi antar satu individu dengan organisasi yang ada pada masyarakat, kedua melalui klik yaitu kelompok kecil orang tanpa struktur formal yang mempunyai pandangan atau kepentingan bersama yang merupakan sistem interaksi satu sama lain pada masyarakat dan jaringan pribadi yaitu hubungan satu individu dengan individu lainnya. Indikatorindikator yang bisa menguraikan diantaranya yaitu derajat sentralitas yaitu siapa orang yang menjadi pusat dalam sebuah jaringan tersebut biasanya dapat digambarkan oleh pemimpin masyarakat, lingkaran gosip, atau orang pertama yang sering mendapat informasi. Kedua melalui tingkat kebersamaan dan tingkat kedekatan antar masyarakat (Prell, 2013).

Berdasarkan hasil wawancara dan observasi, informan AN menyatakan mengenai pengertian jaringan sosial yang ia ketahui yaitu Jaringan sosial yang ada di Kampung Adat 
Kuta yaitu pola komunikasi antar individu dan organisasi seperti yang baik. Di Kampung Adat Kuta terdapat beberapa organisasi yaitu BPD, LPM, DKM, Karang Taruna, Kelompok tani, PKK/Kader yang bisa di akses oleh masyarakat. Hubungan satu jaringan dengan jaringan sosial cukup baik dilihat bagaimana masyarakat adat memanfaatkan semua jaringan tersebut saat sebelum dan sekarang saat pandemi Covid-19, baik dalam kerja sama, saling mengajak satu sama lain, gotong royong dan saat penyampaian informasi. Hal ini terjadi karena masyarakat adat Kampung Kuta memegang teguh nilai adat istiadat yang sudah membudaya menjadi suatu kebiasaan.

Namun tidak bisa dipungkiri bahwa dalam suatu hubungan ada yang baik dan kurang baik, tergantung tingkat kepercayaan, kelekatan dan kedekatan antar satu masyarakat adat dengan yang lainnya. Masyarakat adat Kampung Kuta memanfaatkan jaringan sosial tersebut saat sebelum dan setelah adanya pandemi Covid-19 tetap digunakan, yaitu masyarakat adat akan menghubungi perangkat adat dan dusun yang menjadi pusat informasi dan titik sentral masyarakat yang ada disini.

Tingkat kebersamaan, kelekatan dan kedekatan masyarakat adat Kampung Kuta dapat dilihat melalui pengorbanan yang diberikan satu sama lain, misalnya saat membantu mendirikan rumah, ketika ada yang melahirkan akan ditunggu selama 40 hari, sedangkan yang meninggal ditunggu selama 7 hari. Penyebaran informasi pun di Kampung Adat Kuta terjadi dengan cepat dan luas, biasanya pusat informasi terjadi di warung, sawah, kebun dan pos ronda yang merupakan tempat berkumpul masyarakat adat Kampung Kuta. Selain dari itu saat ada tetangga atau saudara yang membutuhkan, masyarakat adat akan memberi sesuai dengan kemampuan dan apa yang dimiliki akan dipinjamkan.

Pemanfaatan semua jaringan sosial pada masyarakat adat Kuta saat pandemi Covid-19 juga mengalami hambatan seperti tetap menjaga protokol kesehatan yaitu $3 \mathrm{M}$ dan tetap menjalin komunikasi dengan baik saat bertemu atau lewat online, sehingga hubungan antar individu, kelompok dan organisasi pun tetap terjalin dengan baik.

Jaringan sosial yang terjalin di Kampung Adat Kuta, tidak hanya terjalin secara individu, kelompok, organisasi bahkan dengan pihak pemerintah, yaitu saat adanya bantuan. Jenis bantuan yang sudah masuk ke Kampung Adat Kuta yaitu PKH, BPNT, Rastra, KIS, BPJS, KIP, bantuan untuk pertanian, bantuan Covid-19 berupa uang Rp. $600.000,00$, bantuan kuota belajar, bantuan listrik dan bantuan pengadaan protokol kesehatan seperti cek suhu, tempat cuci tangan dan masker.

\section{Harapan Informan terkait Strategi Bertahan Hidup Masyarakat Kampung Adat Kuta Dalam Menghadapi Pandemi Covid-19 Di Kabupaten Ciamis}

Semua informan yang di wawancara memiliki harapan yang sama terkait strategi bertahan hidup yaitu masyarakat adat Kampung Kuta berharap pandemi Covid-19 cepat berlalu, segera berakhir atau memudahkan penjualan hasil pertanian, anakanak bisa sekolah seperti biasa, kegiatan rutinan disini berjalan dengan semestinya.

\section{PEMBAHASAN}

Hasil dari penelitian di lapangan, tujuh aset komunitas diatas dimiliki oleh Kampung Adat Kuta dan dimanfaatkan secara maksimal dalam pelaksanaannya saat pandemi Covid-19. 
Berikut gambaran pemanfaatan tujuh aset sumber daya yang berada di Kampung Adat Kuta :

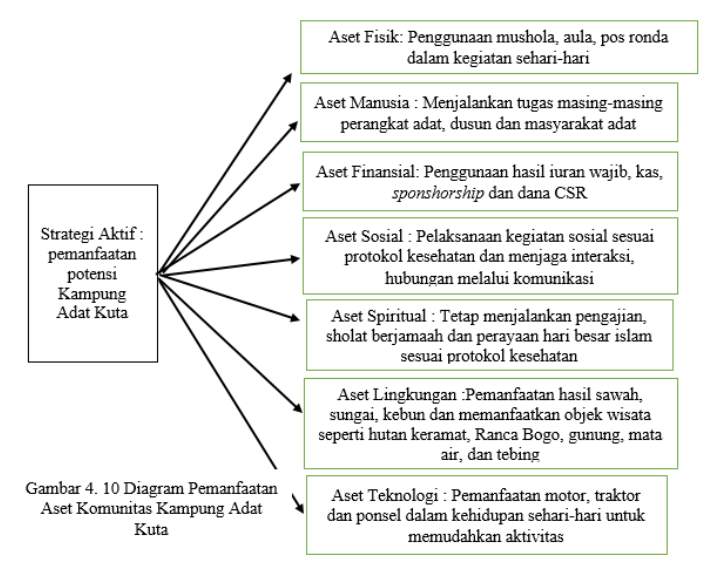

Gambar 1.Pemanfaatan 7 Aset Sumber Daya Kampung Kuta

Pemanfaatan aset fisik yakni mushola untuk beribadah, pengajian, perayaan hari-hari besar, yang sesuai dengan protokol kesehatan. Aula adat juga digunakan sebagai tempat pusat berkumpul. Sedangkan untuk pos ronda digunakan untuk menjaga keamanan.

Sumber daya manusia juga dikerahkan saat pandemi Covid-19 dengan maksimal dalam menjalankan tugas, baik dari perangkat adat serta perangkat dusun. Semua sumber daya finansial pun ikut dimaksimalkan penggunaannya yaitu untuk pelaksanaan kegiatan rutinan, dan membantu masyarakat adat yang mendapatkan musibah.

Kegiatan-kegiatan sosial pun tetap di maksimalkan untuk berjalan dengan semestinya namun memang tetap mematuhi protokol kesehatan. Ritual-ritual tahunan seperti babarit, nyuguh, hajat bumi, saman, nebus weteng, teya, nyangkreb (nyalin) dan ngarupus, serta kegiatan hajatan, pembuatan rumah, melahirkan dan ada yang meninggal tetap berjalan, namun tetap dibatasi. Interaksi dan hubungan komunikasi berjalan melalui gotong royong pada kegiatan-kegiatan diatas dan penukaran informasi terjalin saat berkumpul pada lingkaran-lingkaran gosip di warung atau pos ronda, bahkan ketika ada yang kekurangan masyarakat adat saling membantu seperti keluarga sendiri. Fakta ini pun didukung dengan hasil penelitian dari Wayan, 2020 yang menjelaskan bahwa Desa Adat di Bali dalam mencegah penyebaran Covid-19 yaitu dengan menghindari kerumunan, pemberian bantuan dan melakukan ritual upacara ngeneng ngening.

Aset lingkungan pun tetap digunakan saat pandemi Covid-19, semua masyarakat adat tetap beraktivitas di sawah serta tetap menggunakan peralatan yang menunjang pekerjaannya yaitu traktor dan motor. Sedangkan ketika ada pengunjung yang masuk ke wilayah Kampung Adat Kuta, tetap diperbolehkan namun harus menjaga protokol kesehatan dan pengetatan izin masuk. Penggunaan ponsel pun tetap digunakan oleh anak-anak Kampung Adat Kuta untuk bersekolah online.

Walaupun tidak bisa dimungkiri bahwa dalam pelaksanaan pemanfaatan aset sumber daya tersebut terjadi kendala-kendala seperti pembatasan atau pengetatan protokol kesehatan serta dana, tapi masyarakat adat Kampung Kuta tetap berupaya, agar semuanya bisa dimanfaatkan secara maksimal.

Strategi kedua yang dilakukan oleh masyarakat adat Kampung Kuta yaitu strategi pasif yang merupakan strategi bertahan hidup yang dilaksanakan dengan mengurangi biaya hidup keluarga atau masyarakat (Edi Suharto (2009: 31)). Aspek ini akan di analisis berawal dari dampak pandemi Covid-19 yang dirasakan oleh masyarakat adat Kampung Kuta, berikut 
fakta empiris di lapangan yang dapat digambarkan oleh peneliti :

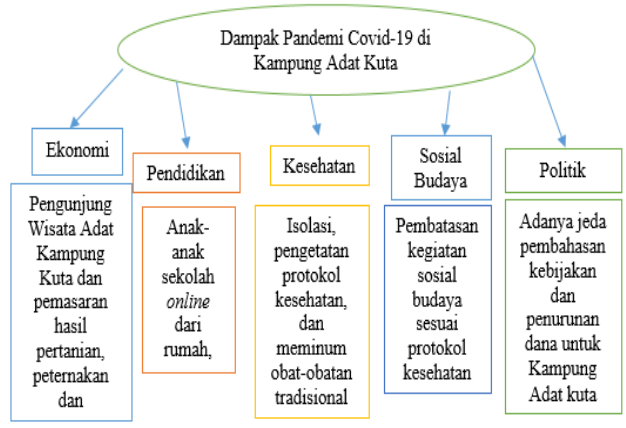

Gambar 2. Skema Dampak Pandemi Covid terhadap Bidang Kehidupan Masyarakat Kampung Kuta

Dampak pandemi Covid-19 pun dirasakan oleh masyarakat adat Kampung Kuta secara keseluruhan, yang paling dominan berdampak yaitu bidang ekonomi dimana masyarakat adat Kampung Kuta tidak bisa memasarkan hasil pertanian ke luar wilayah. Selain sulit untuk pemasaran, harga jual pun turun dengan drastis, paling mencapai setengah harga dari biasanya, bahkan ada beberapa hasil pertanian seperti pisang tidak diterima oleh tengkulak. Hal ini mengakibatkan penghasilan masyarakat adat Kampung Kuta menurun, padahal pengeluaran tetap sama. Kerugian ekonomi yang diakibatkan dari pandemi Covid19 tersebut karena strategi penangangan yang kurang kuat dan daya jual yang menurun (Silpa Hanoatubun, 2020). Kemudian dengan fakta dilapangan bahwa desa wisata adat Kampung Kuta pun ditutup sementara dan sekarang adanya pembatasan jumlah pengunjung. Sehingga, semua pemasukan dari pengunjung wisata pun turun, sehingga mengakibatkan pemasukan untuk masyarakat adat pun berkurang. Sekarang desa wisata adat Kampung Kuta harus menjaga protokol kesehatan.
Dampak pada bidang pendidikan yang dirasakan oleh masyarakat adat Kampung Kuta yaitu banyak anak-anak di Kampung Adat Kuta melaksanakan sekolah online dari rumah. Sedangkan bidang kesehatan dan politik tidak terlalu berdampak pada kehidupan masyarakat adat disana. Hal ini berjalan dengan seperti biasa, namun untuk kegiatan sosial dilaksanakan dengan menerapkan protokol kesehatan.

Semua dampak yang terjadi tidak membuat masyarakat adat Kampung Kuta putus asa untuk tetap menjalankan hidup, karena nilai adat istiadat yang dianut, membuat masyarakat adat Kampung Kuta yakin untuk selalu berupaya agar tetap bisa memenuhi kebutuhan sehari-hari. Strategi yang dilakukan yaitu dengan pemanfaatan iuran wajib, dana CSR dan sponsorship, serta uang kas dari pengunjung yang masuk ke wilayah adat. Semua pemasukan tersebut digunakan secara maksimal untuk membantu masyarakat yang terkena dampak pandemi Covid-19.

Selain upaya tersebut, strategi yang dilaksanakan oleh masyarakat adat yaitu meminimalisir pengeluaran saat pandemi Covid-19 untuk biaya makan, pakaian dan kebutuhan lainnya. Masyarakat adat Kampung Kuta mengambil hasil alam untuk biaya makan sehari-hari, sehingga pendapatan yang diperoleh hanya digunakan untuk biaya sekolah, listrik, bahan bakar dan alat penunjang pertanian, peternakan dan perikanan. Strategi tersebut dilakukan untuk mengurangi biaya agar tetap bisa bertahan hidup (Kusnadi, 2002).

Strategi-strategi pasif lainnya yaitu saling membantu sama lain ketika ada kekurangan, tetap berinovasi dan berkreasi untuk menjual usaha lain, menambah jenis tanaman yang ditanam dan menghubungi pihak 
lain seperti orang-orang terdekat untuk membeli hasil pertanian. Strategi-strategi yang masyarakat adat lakukan sama dengan hasil penelitian jurnal Ekonom Pertanian dan Agribisnis oleh M. Chairul B.U tahun 2019 yang mana para petani di Desa Waeperang menerapkan strategi pasif dengan hidup hemat dan meminjam uang ke kerabat terdekat.

Masyarakat adat Kampung Kuta untuk berstrategi dalam memaksimalkan jaringan sosial di masyarakat sesuai dengan pandangan Edi Suharto yaitu tetap menjalankan hubungan formal baik secara kelembagaan serta lingkungan sosial yang dapat dilihat dari diagram berikut ini :

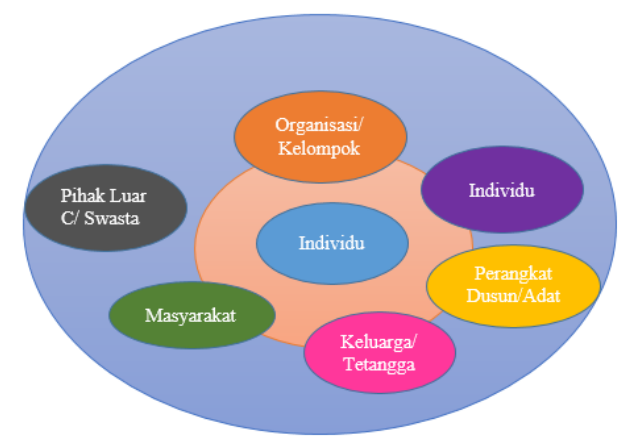

Gambar 3. Diagram Hubungan dalam Lingkungan Sosial

Pemanfaatan jaringan diatas selalu dijalin hubungannya dengan baik dengan pola komunikasi diantara semua individu dalam sebuah sistem (Total Network System, Jensen, 2003). Hubungan tersebut dijaga dengan berkomunikasi dua arah, berbagi informasi saat berkumpul di warung, pos ronda, sawah, dan kebun. Bahkan masyarakat adat akan memanfaatkan jaringan sosial tersebut dengan meminjam kepada tetangga dan toko/warung.

Hal ini didukung dengan kebersamaan dan kedekatan melalui kegiatan gotong royong dan pelaksanaan ritual-ritual tahunan. Strategistrategi tersebut sesuai dengan pendapat
Kusnadi bahwa dengan adanya interaksi pada masyarakat adat Kampung Kuta membuat masyarakat adat saling membantu satu sama lain. Kegiatan saling membantu satu sama lain tersebut terjadi pada sebuah elemen sistem yang saling berinteraksi ( $k$ lik) yang mengalir ke setiap individu tertentu (personal network).

Semua elemen jaringan sosial di Kampung Adat Kuta memiliki tingkat kebersamaan (betweeness) dan tingkat kedekatan (closeness) yang cukup baik, dilihat dari dasar nilai adat istiadat yang di pegang, membuat kedekatan dan keeratan satu sama lain. Semua masyarakat adat Kampung Kuta juga patuh akan posisi terpusat yaitu pemerintah adat dan pemerintah dusun.

Kepatuhan masyarakat adat Kampung Kuta terhadap pemerintah dusun dan adat membuat bantuan dari pemerintah seperti PKH, BPNT, Rastra, bantuan Covid-19 berupa kuota, bebas listrik yang menggunakan 1 paket listrik dan bantuan perlengkapan protokol kesehatan pun dirasakan oleh masyarakat adat Kampung Kuta secara merata, sehingga bisa menjadi upaya untuk bertahan hidup saat pandemi Covid-19.

Hambatan-hambatan yang terjadi saat pemanfaatan jaringan sosial yaitu adanya perbedaan tujuan, miss komunikasi dan sulit menjangkau jaringan terluar, tetapi masyarakat adat Kuta tetap berupaya untuk memanfaatkan jaringan sosial yang paling dekat terlebih dahulu.

Berdasarkan semua strategi yang digunakan, masyarakat adat Kampung Kuta tetap menjunjung tinggi adat istiadat serta tetap melestarikan lingkungan untuk tetap bertahan hidup.

Hal ini selaras dengan penelitian dari Diosey Ramon Lugo-Morin, 2021 juga 
menjelaskan bahwa masyarakat adat tetap bertahan hidup dengan memaksimalkan lembaga informal memainkan peran penting dalam sistem pangan seperti di wilayah Huehuetla, Totonac. Hal tersebut dapat diamati dan ditentukan oleh kekayaan budaya kelompok adat Totonac yang diekspresikan dalam sistem kepercayaan, nilai, dan tradisinya.

Nilai, kepercayaan, dan tradisi di kotamadya dapat menjadi wahana transformasi teritorial dan pergerakan dari wilayah terpinggirkan dengan atribut unik (keyakinan, nilai, tradisi, institusi) ke wilayah budaya dengan potensi untuk mengembangkan sistem pangan daerah.

Banyaknya lembaga informal dalam kelompok masyarakat adat Totonac membuat mereka menegaskan bahwa ada ketahanan kelembagaan yang kuat dari kelompok adat dan merupakan elemen yang menentukan pembangunan lokal di kotamadya Huehuetla. Ini mengarah pada pemikiran ulang pembangunan lokal di wilayah adat dan pedesaan di mana kepercayaan sistem, nilai, dan tradisi yang berlaku.

Munculnya krisis kesehatan seperti yang dipicu oleh pandemi COVID-19 menunjukkan pentingnya sistem pangan asli, sistem yang dirancang oleh nenek moyang ini tidak hanya muncul untuk menyediakan makanan etnis tetapi juga untuk menanggapi tantangan (misalnya, menaklukan,perang, penyakit, pandemi, perubahan iklim). Tinjauan literatur menunjukkan bahwa di seluruh benua (Afrika, Asia, Eropa, Amerika Latin/Amerika Utara dan Oseania) yang signifikan sejumlah masyarakat adat telah mendasarkan strategi penanggulangan COVID-19 mereka pada sistem makanan.
Kemudian penelitian dari Gretchen Walters dkk, 2021 juga menganalisis melalui survei SenseMaker dan studi kasus menunjukkan bahwa COVID-19 telah berdampak kepada masyarakat adat dengan cara yang berbeda. Berdasarkan survei dan studi kasus, adaptasi cepat yang dilakukan dalam rumah tangga di mana pengetahuan tentang praktik tradisional telah dipertahankan; ada peningkatan solidaritas yang paradoks tetapi juga dari pemisahan orang-orang yang dulu bekerja dan tinggal bersama; perayaan tradisional yang mewakili ikatan peluang bagi komunitas terpencil; para pemimpin lokal telah belajar untuk bereaksi cepat dengan meningkatkan kesadaran akan bahaya dan menghindarinya; pengobatan tradisional dan penangkapan ikan secara tradisional, berburu, pertanian dan pengumpulan kembali menjadi penting; banyak desa membuat keputusan untuk mengasingkan diri dari yang lain negara; dan pembatasan terkadang dicegah masyarakat dari melindungi tanah mereka.

\section{KESIMPULAN}

Penelitian ini menggambarkan strategi bertahan hidup masyarakat adat Kampung Kuta dalam menghadapi pandemi Covid-19. Kampung Kuta merupakan merupakan salah satu kampung yang berada di wilayah Desa Karangpaninggal, Kecamatan Tambaksari, Kabupaten Ciamis, Jawa Barat.

Strategi-strategi aktif yang dilakukan oleh masyarakat adat Kampung Kuta dalam menghadapi pandemi Covid-19 yaitu memaksimalkan potensi diantaranya memanfaatkan aset fisik seperti mushola, aula adat dan pos ronda. Aset manusia dimanfaatkan dengan mengerahkan semua perangkat adat dan dusun sesuai tugasnya 
masing-masing. Didukung dengan memaksimalkan aset finansial dari iuran dan dana CSR serta sponsorship untuk membantu masyarakat yang terkena dampak pandemi Covid-19 serta dalam pelaksanaan kegiatan rutinan masyarakat adat.

Kegiatan rutinan yang masih dijalankan oleh masyarakat adat yaitu melaksanakan ritual tahunan, kegiatan hajatan, pembuatan rumah, melahirkan dan ada yang meninggal tetap berjalan, namun tetap dibatasi sesuai dengan protokol kesehatan. Tidak lupa masyarakat adat Kampung Kuta sangat memaksimalkan aset lingkungan berupa sawah dan kebun untuk mencari pendapatan serta objek wisata di Kampung Adat Kuta seperti hutan keramat, Ranca Bogo, Batu Goong, gunung-gunung serta mata air warisan leluhur. Semua aset tersebut digunakan dengan dibantu oleh aset teknologi seperti traktor saat di sawah, motor dan ponsel untuk memudahkan masyarakat adat melakukan aktivitas sehari-hari.

Strategi-strategi diatas pun ditunjang dengan upaya sebagai strategi pasif dalam menghadapi pandemi Covid-19 dengan mengurangi biaya hidup keluarga dan pengeluaran masyarakat. Hal ini dilakukan akibat dampak yang juga dirasakan oleh masyarakat Kampung Adat dalam berbagai bidang, baik bidang ekonomi, bidang kesehatan, bidang sosial budaya ,bidang politik dan bidang pendidikan.

Sikap yang dilakukan masyarakat adat Kampung Kuta dalam menghadapi dampakdampak tersebut yaitu dengan berstrategi mengurangi biaya hidup sehari-hari dengan memaksimalkan potensi alam untuk makan dan memenuhi kebutuhan lainnya, sehingga hasil pertanian yang di dapatkan bisa digunakan untuk membiayai sekolah, listrik, bahan bakar dan alat penunjang pekerjaan masyarakat adat. Strategi-strategi pasif lainnya yaitu saling membantu sama lain ketika ada kekurangan, tetap berinovasi dan berkreasi untuk menjual usaha lain, menambah jenis tanaman yang ditanam dan menghubungi pihak lain seperti orang-orang terdekat untuk membeli hasil pertaniannya.

Selain kedua strategi tersebut, masyarakat adat Kampung Kuta juga melakukan strategi jaringan dalam menghadapi pandemi Covid-19 yaitu dengan melakukan pemanfaatan jaringan antar individu, tetangga/keluarga, masyarakat, organisasi/kelompok, perangkat adat dan dusun bahkan pihak luar/swasta dengan menjalin hubungan yang baik. Didukung dengan kebersamaan dan kedekatan melalui kegiatan gotong royong dalam kegiatan rutinan yang dilakukan. Serta mendapat bantuan dari pemerintah seperti PKH, BPNT, Rastra, bantuan Covid-19 berupa kuota, bebas listrik yang menggunakan 1 paket listrik dan bantuan perlengkapan protokol kesehatan.

\section{DAFTAR PUSTAKA}

Aji, R. H. (2020). Dampak Covid-19 pada Pendidikan di Indonesia: Sekolah, Keterampilan, dan Proses Pembelajaran. Jurnal Sosial dan Budaya Syar-i.

AMAN (Aliansi Masyarakat Adat Nusantara). (2021). Hari Masyarakat Adat Sedunia: Pandemi Tegaskan Resiliensi Masyarakat Adat. https://www.greeners.co/berita/harimasyarakat-adat-sedunia-pandemitegaskan-resiliensi-masyarakat-adat/

AMAN (Aliansi Masyarakat Adat Nusantara). (2021). Kemunduran Negara dan Resiliensi Masyarakat Adat di Tengah Pandemi Covid-19

https://www.aman.or.id/index.php/news/rea $\mathrm{d} /$ kemunduran-negara-dan-resiliensi- 
masyarakat-adat-di-tengah-pandemi-covid19

Andono, A. R. (2020). Desa Tangguh Covid19. Yogyakarta: Universitas Gajah Mada

Anggito, A. Setiawan, J. (2018). Metodologi Penelitian Kualitatif. Sukabumi Jawa Barat : CV Jejak.

Basrun. C. M. (2019). Strategi Bertahan Hidup Petani Padi di Pulau Buru. Jurnal Ekonom Pertanian dan Agribisnis (JEPA)

BNPB. (2020). Penanganan Covid-19. from(https://bnpb.go.id/infografis/updatepercepatan-penanganan-covid19-diindonesia.)

Brager, et all. (1987). Neutron irradiation of Fe$\mathrm{Mn}, \mathrm{Fe}-\mathrm{Cr}-\mathrm{Mn}$ and $\mathrm{Fe}-\mathrm{Cr}-\mathrm{Ni}$ alloys and an explanation of their differences in swelling behavior. Journal of Nuclear Materials, 148, 294-301

Christoper, D. (2013). Pembaru dan Kekuatan Lokal untuk Pembangunan. Australian Community Development and Civil Society Strengthening Scheme (ACCESS) Phase II: TT Danim Sudarwan, Menjadi Peneliti Kualitatif. Bandung: CV Pustaka Setia.

Erni, C et al. (2015). Laporan Evaluasi Tentang Aliansi Masyarakat Adat Nusantara (AMAN). Rainforest Foundation Norway

Fatimah.(2021). Kearifan Lokal Masyarakat Adat Dalam Menghadapi Pandemi Covid-19 ( Studi Literatur ). Jurnal Ilmiah Komunikasi July 2021 Volume 13 No 2

Fahrudin, A. (2012). Pengantar Kesejahteraan Sosial. Bandung: Rafika Aditama.

Hanoatubun, S. (2020). Dampak Covid - 19 Terhadap Perekonomian Indonesia. EdupsiCouns.

Jensen, M.T. (2003). Organizational Communication. Norwegia (NO): Agderforskning Serviceboks 415.

Keraf, A. S. (2010). Etika Lingkungan Hidup. Jakarta: PT Kompas Media Nusantara

Koentjaraningrat, (2009). Pengantar Ilmu Antropologi. Jakarta: Rineka Cipta.

Kusnadi, (2002). Konflik Sosial Nelayan: Kemiskinan dan Perebutan Sumber Daya Perikanan. Yogyakarta: LKis
Maleong, L. J. (2012). Metodologi Penelitian Kualitatif. Bandung: PT Remaja Rosdakarya

Lugo, D.R. Morin. (2021). Global Mapping of Indigenous Resilience Facing the Challenge of the COVID-19 Pandemic. Challenges 2021, 12, 15. https://doi.org/10.3390/challe12010015

Pitana, I. G. (2005). Sosiologi Pariwisata. Yogyakarta : Andi.

Prell, C. (2012). Social Network Analysis: History, Theory \& Metodology. Singapore: SAGE.

Profil Kampung Adat Kuta Tahun 2021

Rothman J, Tropman EJ. (1987). Models of Community Organization and Macro Perspectives: Their Mixing and Phasing: Peacock Publishers.

Rosyadi, (2014). Kajian Kearifan Lokal di Kampung Kuta Kabupaten Ciamis.

Suharto, E. (2006). Membangun Masyarakat Memberdayakan Rakyat. Bandung: Rafika Utama.

Suharto, E. (2009). Kemiskinan dan Perlindungan Sosial di Indonesia. Bandung: Alfabeta.

Sumardi, L. Wahyudiati, D. (2020). Using Local Wisdom to Foster Community Resilience During the Covid-19 Pandemic: A Study in the Sasak Community, Indonesia. Advances in Social Science, Education and Humanities Research, volume 556

Sugiyono. (2013). Metode Penelitian Pendidikan Pendekatan Kuantitatif, Kualitatif, dan R\&D. Bandung: Alfabeta.

Sutaryo. (2020). Buku Praktis Penyakit Virus Corona 19 (Covid-19). Yogyakarta: Gadjah Mada University Press

Walters, G et al. (2021). Covid-19, Indigenous Peoples, Local Communities And Natural Resource Governance. Parks Vol 27 (Special Issue) .2305/Iucn.Ch.2021.Parks27-Sigw.En

Widiowati. Didiet. (2020). Angka Kemiskinan. Webinar Tantangan Pembangunan Berkelanjutan untuk Indonesia 2021 
Windia, W. P. (2020). Peranan Desa Adat di Bali dalam Mencegah Penyebaran Covid19.

\section{Internet}

Peraturan Menteri Dalam Negeri No. 52 Tahun 2004 Tentang Pedoman Pengakuan dan Perlindungan Masyarakat Hukum Adat

(https://www.aman.or.id/wpcontent/uploads/2014/08/PermendagriNomor-52-Tahun-2014.pdf)

Peraturan Daerah Kabupaten Ciamis No. 15 Tahun 2016 Tentang Pengakuan dan Perlindungan Masyarakat Adat Kampung Kuta (https://jdih.ciamiskab.go.id/detail-produkhukum/peraturan-daerah-kabupaten-ciamisnomor-15-tahun-2016-tentang-pengakuandan-perlindungan-masyarakat-hukum-adatkampung-kuta)

Pikobar. Jabar. (2021). Data Penyebaran Covid-19 di Jawa Barat. (https://pikobar.jabarprov.go.id/).

Pikcocid19. Ciamis. (2021) Data Penyebaran Covid-19 di Ciamis. (https://pikcovid19.ciamiskab.go.id/ update 27 Juni 2021)

Worldmeters.(2021). Data Penyebaran Covid19 di Dunia. (https://news.google.com/topstories?hl=en$\underline{\mathrm{ID} \& \mathrm{gl}=\mathrm{ID} \& \mathrm{ceid}=\mathrm{ID}: \mathrm{en})}$ 